\title{
PEREKONOMIAN DUA SEKTOR
}

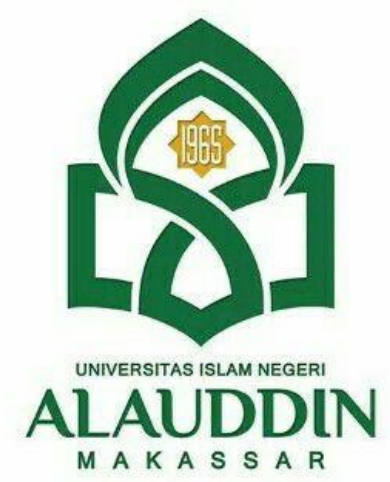

MAKALAH

Pada Mata Kuliah Pengantar Ekonomi Program Studi

Ekonomi Islam Semester 1 Tahun 2021

Oleh:

Wahyuni Putrisarira

NIM.90100121117

Dosen Pengajar:

Sijaruddin, ME

PROGRAM STUDI EKONOMI ISLAM

FAKULTAS EKONOMI DAN BISNIS ISLAM

UIN ALAUDDIN MAKASSAR

2021 


\section{KATA PENGANTAR}

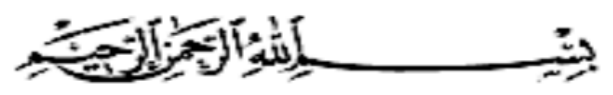

Puji syukur penulis panjatkan ke hadirat Allah Swt. atas rahmat dan hidayahNya sehingga penyusunan makalah ini dapat diselesaikan. Shalawat dan salam semoga tercurahkan kepada Nabi Muhammad Saw keluarga dan para sahabatnya. Makalah dengan judul: "perekonomian dua sektor" ini dimaksudkan untuk menyelesaikan tugas pada mata kuliah pengantar ekonomi. Penulis menyadari bahwa penyelesaian makalah ini tidak akan terwujud tanpa bantuan, bimbingan dan dukungan dari berbagai pihak.

Makassar, 05 Oktober 2021

Penyusunan 


\section{DAFTAR ISI}

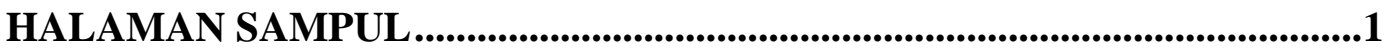

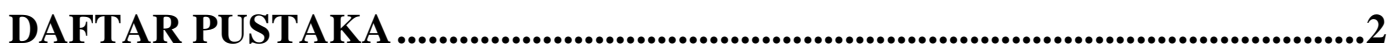

DAFTAR ISI.....................................................................................................................

BAB I PENDAHULUAN.......................................................................................................4
A. Latar belakang .4
B. Rumusan masalah ................................................................................4
C. Tujuan ..................................................................................................................

BAB II PEMBAHASAN .....................................................................................................6

A. Pasar dan harga ...............................................................................................6

B. Pasar barang dan pasar faktor ..................................................................6

C. Pengerttian perekonomian dua sektor ........................................................7

D. Sirkulasi aliran pendapatan ..........................................................................7

E. Pelaku kegiatan ekonomi dan perannya ..................................................10

BAB III PENUTUP ......................................................................................................12
A. Kesimpulan ...................................................................................................12
B. Saran .........................................................................................................12

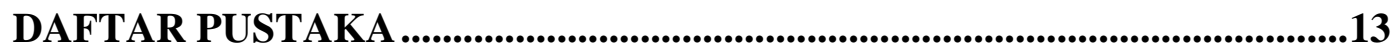




\section{BAB I}

\section{PENDAHULUAN}

\section{A. Latar Belakang}

Perekonomian dua sektor merupakan penyederhanaan dalam mempelajari sistem perekonomian secara keseluruhan. Keseimbangan dalam perekonomian dua sektor merupakan keseimbangan dari sisi pendapatan dan sisi pengeluaran yang dilakukan oleh sektor swasta dengan mengabaikan sektor pemerintah dan sektor luar negri. Pembahasan perekonomian 2 sektor menyangkut konteks tingkat kegiatan ekonomi negara. Sehingga perekonomian 2 sektor membicarakan tentang pendapatan nasional atau permintaan agregat atau penawaran agregat. Namun keseimbangan perekonomian yang dibangun dengan asumsi sederhana dimana hanya ada 2 pelaku ekonomi.

\section{B. Rumusan Masalah}

Berdasarkan latar belakang yang telah di uraikan penulis maka ada beberapa rumusan masalah, yaitu:

1. Apa definisi pasar dan harga?

2. Apa definisi pasar barang dan pasar faktor?

3. Apa definisi perekonomian dua sektor dan bagaimana sirkulasi dari perekonomian dua sektor? 
4. Siapa pelaku ekonomi dua sektor dan apa perannya?

\section{Tujuan}

Berdasarkan rumusan masalah yang telah dituangkan, maka tujuan penulisan ini adalah:

1. Untuk memmahami definisi dari pasar dan harga.

2. Untuk memahami pengaruh pasar barang dan pasar faktor dalam perekonomian dua sektor ini.

3. Untuk memahami definisi dari perekonomian dua sektor.

4. Untuk memahami sirkulasi dari perekonomian dua sektor.

5. Untuk mengetahui pelaku dan peran dari perekonomian dua sektor. 


\section{BAB 11}

\section{PEMBAHASAN}

\section{A. Pasar Dan Harga}

Pasar mempunyai kaitan dengan ekonomi masyarakat, baik produksi, distribusi, dan konsumsi. Dalam hal ini pasar dapat diartikan sebagai arena distribusi atau pertukaran barang, di mana kepentingan produsen dan konsumen bertemu ${ }^{1}$. Pasar juga dapat didefinisikan sebagai institusi atau mekanisme di mana pembeli dan penjual bertemu dan secara Bersamaan mengadakan pertukaran barang. Pasar berfungsi untuk memperlancar proses penyaluran barang dan jasa dari produsen ke konsumen. Pasar akan menetapkan harga suatu barang atau jasa tertentu sesuai dengan permintaan dan penawaran yang terjadi di pasar yang telah disepakati oleh produsen dan konsumen.

Harga adalah sejumlah uang sebagai alat tukar untuk memperoleh produk atau jasa atau dapat juga dikatakan penentu nilai suatu produk. Menurut Tjiptono secara sederhana harga dapat diartikan sebagai jumlah uang (satuan moneter) atau aspek lain (non moneter) ysng mengandung kegunaan tertentu yang diperlukan untuk mendapatkan suatu jasa ${ }^{2}$.

\footnotetext{
${ }^{1}$ Victor M. Manek Kiik, 'Kajian Faktor-Faktor Yang Mempengaruhi Tidak Optimalnya Fungsi Pasar Tradisional Lolowa Dan Pasar Tradisional Fatubenao Kecamatan Kota Atambua - Kabupaten Belu', 2006.

2 Dita Amanah, 'Pengaruh Harga Dan Kualitas Produk Terhadap Kepuasan Konsumen Pada Majestyk Bakery', Jurnal Keuangan \& Bisnis, 2010.
} 


\section{B. Pasar Barang Dan Pasar Faktor}

Pasar barang adalah pasar di mana rumah tangga (sebagai pembeli) dan perusahaan (sebagai penjual barang dan jasa) berinteraksi. Konsumen membeli barang dan jasa dari perusahaan dan menyerahkan uang sebagai pembayaran. Sehingga uang tersebut dapat perusahaan gunakan untuk membeli input di pasar faktor.

Pasar faktor adalah pasar input (sumber daya) yang digunakan perusahaan dalam proses produksi ${ }^{3}$. Di pasar faktor, rumah tangga dan perusahaan berperan secara terbalik dari pasar barang. Di pasar ini, perusahaan sebagai pembeli, sedangkan rumah tangga sebagai penjual tanah, tenaga kerja, modal, dan kemampuan mengambil risiko (sebagai wirausaha). Di sini, uang berpindah dari perusahaan ke rumah tangga.

\section{Pengertian Perekonomian Dua Sektor}

Perekonomian dua sektor adalah perekonomian yang terdiri dari dua pelaku interaksi yaitu sektor rumah tangga dan sektor perusahan ${ }^{4}$ tanpa campur tangan sektor pemerintah dan luar negri. Dengan demikian sisi pendapatan dan sisi pengeluaran hanya dibentuk oleh dua bagian yaitu pada sisi pengeluaran terdapat pengeluaran konsumsi rumah tannga dan pengeluaran investasi dari perusahaan. Sehinnga aliran pendapatan biasanya hanyalah menunjukan aliran faktor produksi, Perekonomian dua sektor ini dianggap sebagai aktivitas ekonomi yang paling sederhana.

\section{Sirkulasi Aliran Pendapatan Dan Pengeluaran}

\footnotetext{
3 Jaidil Kamal, 'Pasar Faktor Produksi Dalam Perspektif Ekonomi Islam', Jurnal An-Nahl, 2020.

${ }^{4}$ Zaenal Abidin and Abd Muhaemin, Pengantar Ekonomi Makro, Angewandte Chemie International Edition, 6(11), 951-952., 2020.
} 
Sirkulasi aliran pendapatan adalah sebuah model yang menggambarkan bagaimana interaksi antara pelaku ekonomi menghasilkan pendapatan yang digunakan sebagai pengeluaran dalam upaya memaksimalkan nilai kegunaan (utility) masing masing pelaku ekonomi.

Siklus pengeluaran adalah serangkaian kegiatan yang terkait dengan perolehan dan pembayaran barang dan jasa. Kegiatan-kegiatan ini meliputi penentuan apa yang perlu dibeli dan lain sebagainya. Berikut gambar aliran dari dua sektor tersebut.

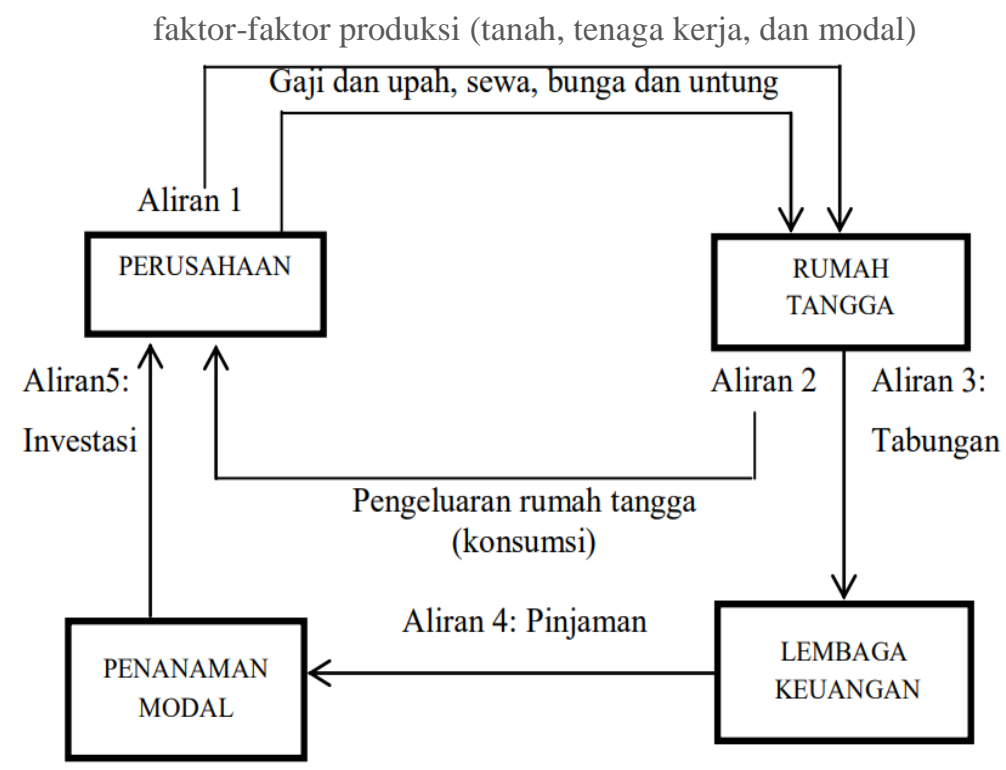

Penjelasan dari aliran-aliran dua sektor diatas adalah:

- Aliran 1: sektor perusahaan menggunakan faktor-faktor produksi yang dimiliki rumah tangga dan faktor-faktor produksi tersebut memperoleh pendapatan berupa upah dan gaji, sewa, bunga dan untung. 
- Aliran 2: sebagian besar pendapatan yang diterima rumah tangga akan digunakan untuk konsumsi, yaitu membeli barang yang dihasilkan oleh sektor perusahaan.

- Aliran 3: sisa pendapatan yang tidak digunakan untuk konsumsi akan ditabung pada lembaga keuangan.

- Aliran 4: para pengusaha meminjam dana kepada Lembaga keuangan untuk melakukan investasi.

Lebih jelasnya bahwa rumah tangga konsumen adalah sebagai pemilih faktorfaktor produksi. Faktor-faktor tersebut berupa tanah, modal, tenaga dan lain sebagainnya yang akan ditawarkan kepada rumah tangga produsen. Penawaran faktor produksi oleh rumah tangga ini akan bertemu dengan permintaan faktor produksi oleh perusahaan. Perusahaan menggunakan faktor produksi untuk kegiatan produksi ${ }^{5}$ yang menghasilkan barang dan jasa. Hasil dari produksi tersebut digunakan perusahaan untuk memberi gaji, profit, sewa, lahan, dan lain sebagainya kepada pemilik faktor produksi. Selain itu pendapatan perusahaan digunakan lagi untuk keberlangsungkan produkasi, konsumsi, dan pembelian barang untuk perusahaan. Interaksi ini terjadi pada pasar faktor produksi. Sedangkan di pasar barang, terjadi interaksi antara perusahaan sebagai penghasil barang dan jasa dengan konsumen sebagai pengguna barang dan jasa. Sehingga terjadi hubungan yang saling menguntungkansatu sama lain. Dalam gambar diagram diatas juga terlihat arus aliran uang dari masing-masing rumah

\footnotetext{
${ }^{5}$ Dr.Sirajuddin SE.,M.Si, Pengantar Teori Ekonomi Makro, 2012.
} 
tangga. Rumah tangga konsumen menerima upah, sewa, bunga, dan keuntungan dari perusahaan sebagai balas jasa atas penyerahan faktor produksi. Perusahan itu sendiri menerima uang pembayaran atas barang dan jasa yang dibeli. Selain itu pendapatan yang diterima oleh rumah tangga konsumen tidak semua digunakan untuk konsumsi. Sisa pendapatan tersebut akan di tabung dalam lembaga keuangan baik bank ataupun bukan bank. Sektor rumah tangga akan mendapatkan bunga dari yang ditabungnya dan perusahaan yang memerlukan investasi akan meminjam dari tabungan tersebut.

\section{E. Pelaku Kegiatan Ekonomi Dan Perannya}

Pelaku ekonomi adalah subjek baik perorangan maupun badan (organisasi) atau pemerintah yang melakukan kegiatan ekonomi seperti produksi, dan distribusi. Sedangkan pelaku ekonomi dua sektor atau disebut juga dengan perekonomian sederhana adalah kegiatan ekonomi yang hanya ada dua pelaku kegiatan ekonomi diantanya:

1. Rumah tangga keluarga (konsumen) yang berperan sebagai pelaku ekonomi yang bertindak sebagai konsumen, Kegiatan konsumsi yang dilakukan rumah tangga keluarga, misalnya barang pokok seperti makanan, air dan listrik. Dan juga sebagai pemilik faktor produksi. Faktor produksi yang terdapat pada rumah tangga antara lain tenaga kerja, tenaga usahawan, barang modal, kekayaan alam, serta harta tetap seperti tanah dan bangunan.

2. Rumah tangga perusahaan (produsen) yang bertujuan menghasilkan barang dan jasa yang dibutuhkan konsumen. Sebagai pelaku ekonomi. Kegiatan 
ekonomi yang dilakukan oleh rumah tangga perusahaan meliputi produksi, konsumsi, distribusi, Maksudnya:

- Perusahaan bisa berperan sebagai produsen, di mana perusahaan merupakan tempat berlangsungnya produksi.

- Perusahaah juga dapat berperan sebagai konsumen ialah dengan melakukan kegiatan konsumsi seperti Pengadaan bahan-bahan yang merupakan bahan pokok produksi.

- Perusahaan juga berperan sebagai distributor atau agen, serta kegiatan ekonomi yang dilakukan perusahaan yang dapat memberikan kesejahteraan bagi karyawan perusahaan dan masyarakat. 


\section{BAB III PENUTUP}

\section{A. Kesimpulan}

Perekonomian dua sektor atau perekonomian sederhana adalah suatu perekonomian yang hanya terdiri dari sektor rumah tangga dan sektor perusahaan. Tingkat kegiatan ekonomi ditentukan oleh jumlah dan mutu daripada faktor-faktor produksi. Dalam perekonomian dua sektor sumber pendapatan yang diperoleh rumah tangga berasal dari perusahaan yang meliputi gaji, upah, sewa, bunga dan keuntungan yang sama nilainya dengan pendapatan nasional.

\section{B. Saran}

Tentunya saya sadar bahwa masih banyak kekurangan yang saya miliki, baik dari tulisan maupun bahasan yang kami sajikan, oleh karena itu mohon di berikan sarannya agar saya bisa membuat makalah lebih baik lagi. Dan semoga makalah ini bisa bermanfaat bagi kita semua, dan menjadi wawasan kita dalam memahami perekonomian dua sektor. 


\section{DAFTAR PUSTAKA}

Abidin, Z., \& Muhaemin, A. (2020). Pengantar Ekonomi Makro. In Angewandte Chemie International Edition, 6(11), 951-952.

Slat, A. H. (2013). Analisis Harga Pokok Produk Dengan Metode Full Costing Dan Penentuan Harga Jual. Jurnal Riset Ekonomi, Manajemen, Bisnis Dan Akuntansi.

Kiik, V. M. M. (2006). Kajian Faktor-Faktor Yang Mempengaruhi Tidak Optimalnya Fungsi Pasar Tradisional Lolowa Dan Pasar Tradisional Fatubenao Kecamatan Kota Atambua - Kabupaten Belu.

Kamal, J. (2020). Pasar Faktor Produksi Dalam Perspektif Ekonomi Islam. Jurnal AnNahl.

Shakespeare, W. (2017). Pemerataan Hirarki Orde-Barang Pasar Di Kota Palembang. Jurnal Swarnabhumi.

SE.,M.Si, D. S. (2012). Pengantar Teori Ekonomi Makro.

Amanah, D. (2010). Pengaruh harga dan kualitas produk terhadap kepuasan konsumen pada majestyk bakery. Jurnal Keuangan \& Bisnis. 